2021, Volume 16, ATEE 2020 - Winter Conference. Teacher Education for Promoting WellBeing in School. Suceava, 2020, pages: 410-417|

\section{Some Aspects of the Creative Potential in Primary School Children}

\section{Ramona Elena ROTARU ${ }^{1}$}

${ }^{1} \mathrm{PhD}$ Student, State University of Moldova, Chisinau, Republic of Moldova, ramonaelenarotaru@gmail.com
Abstract: $A$ notable theme in much recent primary education has been the concept of creativity. Nowadays it is highlighted the fact that creativity is directly responsible for the progress of the society. Creativity and creative potential are still seen as two abstracts concepts because literature in the field is updating day by day. The curriculum contributes the developing of trans and interdisciplinary activities. Throughout time, the most important innovations in different domains were possible only with the belp of human who wanted to create something new, original and innovative. In this case, creativity plays a very important role. Developing the capacity of being creative, it is essential for surviving, as each of us is in great need of novelty and originality. The link between creativity and creative potential is very thin because it positively influences at the same time the educational process. In the article, the novelty is highlighted through the connections between creativity and creative potential in education and also, there are presented few theoretical interpretations of each concept. In order for an adult to become creative, fostering creativity and stimulating creative potential from an early age is required. The school system remains the main instrument, which society uses to cultivate and enhance creativity in young members, of school age. In this sense, the systemic modernization of education, in the light of pedagogy of creativity, is necessary. Although, the school play an essential role in training primary school children in order to be able to use their full creative potential in future productive activities. At the same time, creativity represents a condition of efficiency in both work and education. Creativity and creative potential in education stands for an important factor in developing primary school children in order to obtain an autonomous and creative personality.

Keywords: creativity; creative potential; stimulation of creativity; primary education; primary school children.

How to cite: Rotaru, R. E. (2021). Some Aspects of the Creative Potential in Primary School Children. In O. Clipa (vol. ed.), Lumen Proceedings: Vol. 16. ATEE 2020 - Winter Conference. Teacher Education for Promoting Well-Being in School. Suceava, 2020 (pp. 410-417). Iasi, Romania: LUMEN Publishing House.

https://doi.org/10.18662/lumproc/atee2020/28 


\section{Introduction}

In the current educational process, marked by continuous change and constant readjustment to new educational situations, creativity has contributed to the formation of a society in which each individual must solve various unexpected problems and find many original, inventive, varied, ingenious, and creative solutions. The changes of the age in which we live also come with the changes in the educational process, which is taking place at an increasingly accelerated pace. At the same time, in the context of today's society, the concept of creativity, and understanding of pupils' creative potential since primary school is important. Moreover, the current topic is not widely addressed, but it could instead become one of the central priorities of global education.

Therefore, the study of creativity has an important role in education and is a key factor in the development of the personality of primary school students. In addition, by knowing the creative potential of children we can prepare the next generation to cope with the next transformations of education and at the same time, of life. The current educational process, which is focused on the needs of the child, has an extraordinary role in socio-human progress if it is well valued.

In most historical research on the concept of creativity, psychologists have made the social demand for tools that assess the creative potential only after World War II. Both academic achievements and scores on regular intelligence tests have proven to be insufficient in identifying the ability to invent or find solutions in new situations. However, at that time, psychology had nothing to offer because research on creativity was limited (Gruber \& Bödeker, 2005). An important hypothesis that highlights the development of tests to measure creative potential stands for the fact that creativity is a general trait of people. That is why scientists conclude that they can use answers on an unusual test to foretell creative production in fields such as painting, literature, poetry, and so on. Nonetheless, there is a debate in the specialty literature because research results are contradictious with reference to whether creativity is a general trait (Weisberg, 2006).

The novelty of the current theme is represented by creative potential and creativity, which can be one of the most fascinating processes of human personality, representing the highest line progression of our educational process. Given that we are in a constantly changing society, creativity should become a defining pillar of human progress. The success of progress and evolution should focus on stimulating the creativity of the primary school children. 


\section{Some theoretical aspects of the creative potential and creativity of primary school children}

Many specifications of creativity are based on theoretical concepts. Overall, we can define creativity at the same time as an ability, attitude, and process. It stands for the ability to invent or to imagine something new. On top of that, it is an ability that creates ideas, gives solutions, fosters constructive thoughts by using distinct schemes, changes, and reproduction of actual ideas. On the one hand, the creative potential of the child in primary school is outlined by agreement, acceptance of change, and something new, and on the other hand, willingness to cope with new ideas and being openminded, flexible. The creative process is distinguished by hard work, a perpetual process of thoughts whilst thinking about the solutions, spontaneity, and transparency (Keklak, 2015).

In most research about creativity, psychologists realized the social and educational importance of potential creativity, only after the end of World War II. Both specialized works of literature alongside the results of the intelligence tests have proved insufficient in identifying the ability to invent or find solutions in new, original situations. However, psychological studies regarding the research of creativity were poor at that time. From a historical perspective, in terms of approaching creative traits can be explained psychometrically in order to stimulate the creation, supported by the first steps in the research of this concept. The study of creativity in that period can rather be identified and selected to individuals with high creative potential when details about creative activities are presented (Gruber \& Bödeker, 2005, pp. 3-4).

The purpose of the current study spots out that each of us has a certain part of the creative potential and stimulating of such a potential that is affected by individual needs, proper interests, motives, and also, personal traits. These traits, which tend to the individual to be resistant to psychological stress, work-related stress, and stress-related to life difficulties. The point of reference for creative personality identification is not as one, but personality traits usually for creative individuals are defined by psychologists. This was completed on the characterization's support of meaningful individuals carrying out genuine creative activities. Such personality traits accelerate the stimulation of creativity and therefore assist while facing problem-solving. These traits are:
- Persistence;
- Self-confidence;
- Courage;
- Curiosity; 
- Intuition;

- Tirelessness;

- $\quad$ Ability to work intensively;

- $\quad$ Ability to put the work to an end;

- Independence and self-reliance;

- Ability to take a risk;

- Ability to accept a defeat;

- Willingness to overcome the obstacles and difficulties;

- $\quad$ To cope with the traits defined as conflicting (Keklak, 2015).

A. Cropley pointed out that neither learning about creativity nor simply being creative is enough. Moreover, in order to highlight the creative potential of primary school children, a conducive educational environment is needed that combines conventional learning with creative activities. It is also true that in the literature, several writers have pointed out that factors such as personal development, self-fulfillment, activation of individual potential, along with similar characteristics are specific for creative and original individuals (Cropley, 1997, pp. 13-15).

\section{The link between creative potential and creativity}

The main objective of this article is to highlight the link between creative potential and creativity. First, we will present some conceptual clarifications about creativity and creative potential in education, after which we will discuss the connection between the two concepts in the educational process.

Plucker, Beghetto, and Dow (2004, p. 90) propose the following definition in the subsequent lines: Creativity is the interaction between aptitude, process, and environment through which an individual or group produces a perceptible product that is both new and useful in a social context. This definition conducts a more effective understanding of both researchers and research beneficiaries, such as educators, teachers and those who are not specialists in the field.

Al. Roşca (1981, p. 11) defines creativity as a superior form of buman activity, which has become an important issue of scientific research in many countries. In addition, the development of the creative abilities of the individual can be achieved only with technical-scientific progress.

Moreover, the concept of creativity is not clearly defined, despite the fact that many writers, art critics, economists, psychologists, pedagogues, and philosophers have their own variant (Stein, 1974). On the one hand, creativity can represent a buman capacity and not a process, specifically, producing original, innovative things or ideas, which are useful to society (Cojocaru, 1972). On the other hand, the concept can also represent the movement or 
process that leads to an original product, being identified as an objective criterion of creativity. Moreover, Al. Roşca (1972, p. 9) highlights the idea that through creativity we can understand the psychological factors of creative performance.

The creative potential in education is a predominant common theme in several scientific pieces of research included in this issue. Although the creative potential is probably among the least defined of the concepts in psychology, it certainly represents an important role in the literature of creativity (Karwowski, 2015). J. P. Guilfford explains that potential psychological factors are represented by creative potential, which stands for any intellectual ability that can contribute to the success of creative production (Stein, 1974 , p. 7). The creative potential is the result of three groups of psychobehavioral factors, according to the psychological models proposed by J.S. Renzulli and T.M. Amabile. These psycho-behavioral factors are the following:

a) skills for discipline (knowledge and skills of scientific thinking);

b) creative thinking skills;

c) interests and intrinsic motivation (perseverance, employment).

The three factors contribute to the establishment and development of a child's personality and signify a primary, initial, innate availability for each primary school child, but at the same time in continuous development through creative learning in an advantageous and favorable educational environment (Sevinci, 2015, p. 62).

On the one hand, M. I. Stein believes that there may be a certain level of creative potential or it may be completely absent. For the most part, those who are directly involved in the educational process, more precisely, the primary beneficiaries of education, the students, have to wait until they show their creativity or not. The situation in which the manifestation of creativity appears or does not appear represents the moment in which the researcher deduces whether or not the student benefited from the initial creative potential. On the other hand, implicitly or explicitly, personality theorists make assumptions about the nature of the individual. Those who adopt the theory of their realization and who focus on the idea that the individual, respectively the student in primary education is oriented towards personal development, would come to the idea that each of us has a creative potential (Shapiro \& Guilford, 1994, pp. 8-9).

The creative potential of primary school children becomes possible through the transfer of creative abilities and can be stimulated through creative activities. Moreover, creativity is educable, as A.M. Popescu (2016, p. 18) claims, and its stimulation at school age is a key factor in education because schooling is the period that includes the most important acquisitions 
in the education process. During schooling, the pupil's personality develops and at the same time combines the most valuable acquisitions that are extremely essential in the development of an autonomous and creative personality.

\section{Specific features of stimulating creativity in primary education}

S.I. Shapiro and E.P. Torrance noted that sometimes educational systems do not encourage the development of creative skills, but on the contrary (Shapiro \& Guilford, 1994, p. 10; Torrance, 1963, p. 14). I. Taylor believes that today's education system does not always stimulate creativity, but rather promotes standard thinking. On the one hand, blocking to some extent the development of critical thinking, focusing on the storage of information and the reproduction of information. On the other hand, it is important the development of the ability of the primary school children to have their own opinion, judgment, and to operate in an original and independent way (Taylor, 1964).

In the scientific literature, the initial principle in approaching and educating creativity in the primary school system is achieved through the direct participation of pupils in the activity and their actual engagement in activities that stimulate creative skills. Their intense development is accomplished mainly in problem-solving situations and in the process of independent activity to solve difficult situations that contain new parameters. With a current approach to learning, primary school children have to go through the stages of their own discoveries, such as:

- developing hypotheses;

- reorganization of facts;

- transforming the systems until obtaining an adequate response;

- checking solutions (Țăpurin, 2017, p. 42).

In primary education is needed a program to stimulate pupils' creativity, which can focus on associating the particularities of stimulating creative abilities. From this point of view, the content of the educational process in the primary cycle, which combines various creative and varied activities, from a trans and interdisciplinary perspective, can favor the development of primary school children. Certainly, focusing on specific heuristic activities and multiple problem-solving situations will contribute to the development of an autonomous, flexible, and creative personality. 


\section{Conclusions}

From the perspective of the analysis of literary interpretations, it becomes evident that the two concepts, creativity, and creative potential, have a connection with education and contribute to the development of the child's personality in primary education.

Hence, the creative potential of children becomes possible only when the creative abilities can be stimulated. The connection between the two concepts with education is much deeper because the study of creativity requires an even more elaborate approach to individual characteristics that require an empirical understanding and a persuasive searching for creative elements.

In recent years, primary education has been marked by many changes, but not all have been greeted with equal enthusiasm. A good example is that of creativity. The stimulation of primary school children's creativity is in benefit of both for the current educational process and for society.

As a result, many creativity researchers have addressed the topic of creative potential, but few have taken this study to its depth. In other words, belabored theories about creativity and empirical studies of creative potential are presented in the educational process as the key factors in the development of today's society and in educational system.

Note: This article draws on recent doctoral research.

\section{References}

Cojocaru, C. (1972). Creativitate şi inovație [Creativity and innovation]. Editura Enciclopedică Română. p. 45.

Cropley, A. (1997). More ways than one: Fostering creativity. Ablex Publishing Corporation. pp. 13-15.

Gruber, H., \& Bödeker, K. (2005). Creativity, Psychology and The History of Science. Springer.

Karwowski, M. (2015). Notes on Creative Potential and Its Measurement. Journal of Creativity. Theories - Research - Applications (CTRA), 2(1), 4-16. https://content.sciendo.com/view/journals/ctra/2/1/articlep4.xml?tab body $=$ pdf

Keklak, R. (2015). Creative personality in relation to the Big five personality model. In V. Kunova \& M. Dolinsky (Eds.), Current Issues of Science and Research in the global World (pp. 201-207). Taylor \& Francis Group. https://doi.org/10.1201/b17801 
Plucker, J. A., Beghetto, R. A., \& Dow, G. T. (2004). Why Isn't Creativity More Important to Educational Psychologists? Potentials, Pitfalls, and Future Directions in Creativity Research. Educational Psychologist, 39(2), 83-96. https://www.researchgate.net/publication/233298152 Why Isn't Creativi ty More Important to Educational Psychologists Potentials Pitfalls an d Future Directions in Creativity Research

Popescu, A. M. (2016). Dezvoltarea creativității la copiii de vârstă preşcolară în procesul educațional - Particularitățile dezvoltării creativității în procesul educaţional [Development of creativity in preschool children in the educational process - Peculiarities of creativity development in the educational process]. Analele Universității „Constantin Brâncuşi”, Seria Ştiinţe ale Educației, 1, 18-25. http://www.utgjiu.ro/revista/dppd/pdf/201601/2_Ana-Maria\%20Popescu.pdf

Roşca, A. (1972). Creativitatea [Creativity]. Editura Enciclopedică Română. p. 9.

Roşca, A. (1981). Creativitatea generală şi specifică [General and specific creativity]. Editura Academiei Republicii Socialiste România. p. 11.

Sevinci, O. (2015). Studiu privind influența şcolii în educarea creativității elevilor [Study on the influence of school in educating pupils' creativity]. Orizont Didactic, 50, 62-63. https://orizontdidactic.files.wordpress.com/2016/03/ studiu-influenta-scolii.pdf

Shapiro, R. S., \& Guilford, J. P. (1994). The Inteligence and Creation. Mc Graw Hill. 67 p.

Stein, M. I. (1974). Stimulating creativity. Academic Press. 93 p.

T,ăpurin, A. (2017). Dezvoltarea creativității la copiii de vârstă preşcolară în procesul educational [Developing creativity in preschool children in the educational process] [Doctoral dissertation in psychology, Universitatea Pedagogică De Stat „Ion Creangă’]. Chişinău, 307 p. http://www.cnaa.md/files/theses/2017/52675/adriana tapurin thesis.pdf

Taylor, I. (1964). Creativity - Intelligence Distinction. Holt, Rinenhart \& Winston. 162 p.

Torrance, E. P. (1963). Education and the creative potential. Press. 93 p.

Weisberg, R. (2006). Creativity. Understanding Innovation in Problem Solving Science, Invention, and the Arts. John Wiley \& Sons. p. 483. 